\section{Expression of a Gene Encoding the Carrot HSP17.7 in Escherichia coli Enhances Cell Viability and Protein Solubility Under Heat Stress}

\author{
Hyesoon Kim and Yeh-Jin Ahn' \\ Department of Life Science, College of Natural Sciences, Sangmyung \\ University, 7 Hongji-dong, Jongno-gu, Seoul 110-743, Korea
}

Additional index words. Daucus carota L., heat shock protein, heat stress, molecular chaperone, oligomeric complex, protein denaturation, thermotolerance

\begin{abstract}
DcHSP17.7, a small heat shock protein from carrot (Daucus carota L.), was expressed in Escherichia coli to examine its functional mechanism under heat stress. When transformed cells expressing DcHSP17.7 were exposed to $50^{\circ} \mathrm{C}$ for $1 \mathrm{~h}$, the number of viable cells was $\approx 4$-fold higher than that of control. When the amount of soluble proteins was compared, it was more than twofold higher in transformed cells expressing DcHSP17.7 than that in control, suggesting that DcHSP17.7 may function as a molecular chaperone preventing heat-inducible protein degradation. Native-PAGE followed by immunoblot analysis showed that in transformed $E$. coli, DcHSP17.7 was present in an oligomeric complex, $\approx 300 \mathrm{kDa}$ in molecular mass, on isopropyl b-D-thiogalactopyranoside treatment. However, the complex rapidly disappeared when bacterial cells were exposed to heat stress. In carrot, DcHSP17.7 was found in the similar-sized complex $(\approx 300 \mathrm{kDa})$, but only during heat stress $\left(40^{\circ} \mathrm{C}\right)$, suggesting that the functional structure of DcHSP17.7 may be different in transformed $E$. coli from that in carrot.
\end{abstract}

Plants, being sessile, are more vulnerable to daily and/or seasonal temperature elevation in their natural environment. Moreover, average global surface temperature is on the rise as a result of global warming. The Intergovernmental Panel on Climate Change projected that annual global temperature will likely increase by 1.1 to $6.4{ }^{\circ} \mathrm{C}$ during the 21 st century (Keller, 2007). In plants, elevated temperatures can disrupt essential metabolic processes such as photosynthesis, respiration, and carbon fixation (Pollock et al., 1993). Accordingly, heat stress negatively impacts agricultural crop production and product quality. Lobell and Field (2007) reported that over the last two decades, warming temperatures have caused annual losses of $\approx 40$ million metric tons, worth $\$ 5$ billion, for the three major agricultural crops, wheat, maize, and barley. Accordingly, it is important to understand plant heat stress physiology and develop crop plants that show enhanced thermotolerance and production under heat stress.

All living organisms, including plants, respond to heat stress $\left(10\right.$ to $15{ }^{\circ} \mathrm{C}$ above

\footnotetext{
Received for publication 31 Dec. 2008. Accepted for publication 26 Feb. 2009.

This work was supported by a Korea Research Foundation Grant funded by the Korean Government (MOEHRD, Basic Research Promotion Fund, KRF-2007-531-F00002) and the BioGreen 21 Program Grant (Code \#20070501034003) funded by the Rural Development Administration, Korea.

${ }^{1}$ To whom reprint requests should be addressed; e-mailyjahn@smu.ac.kr.
}

their optimal growth temperatures) by producing a set of proteins called heat shock proteins (HSPs; Wahid et al., 2007). In eukaryotic organisms, HSPs are classified into five different classes, HSP100, HSP90, HSP70, HSP60, and small (sm) HSPs (15 to $42 \mathrm{kDa}$ ), based on their molecular masses. In plants, smHSPs are the most dominant and abundant HSPs produced on heat stress (Waters et al., 1996). It was reported that there are 19 open reading frames, which code for smHSP-related proteins in the Arabidopsis genome (Scharf et al., 2001). Under normal growth temperatures, most smHSPs are not detected in vegetative tissues. However, on heat stress, smHSPs can be synthesized within minutes and accumulate up to $1 \%$ of total cellular proteins (Hsieh et al., 1992). Even after heat stress has been eased, some smHSPs are very stable with half-lives of 30 to $50 \mathrm{~h}$ (DeRocher et al., 1991). These results suggest that smHSPs play an important role in enhancing thermotolerance in plants during heat stress and/or subsequent recovery.

Although the correlation between the synthesis of smHSPs and thermotolerance has been reported, their cellular and molecSome smHSPs are reported to function as molecular chaperones mainly in vitro when analyzed using model substrates (Basha et al., 2006; Giese and Vierling, 2002). Under heat stress, molecular chaperones bind to partially unfolded/denatured proteins to prevent further aggregation and/or promote renaturation of the proteins. Accordingly, the role of molecular chaperones under heat ular mechanism is not yet fully understood. stress is critical for cell viability and survival of organisms.

To understand the function of smHSPs, it is important to examine their structure during heat stress. One of the notable characteristics of smHSPs is their organization into large oligomeric structures (Haslbeck et al., 2005). In a cellular environment, smHSPs are found in large complexes with molecular masses of 200 to $500 \mathrm{kDa}$ (Kirschner et al., 2000; Young et al., 1999). These complexes are known to be homo-oligomeric (Suzuki et al., 1998). Moreover, on prolonged heat stress, some plant smHSPs are found in much larger insoluble structures (greater than $1 \mathrm{MDa}, 40$ $\mathrm{nm}$ in diameter) named heat shock granules (HSGs; Sun et al., 2002). They are believed to be reservoirs for unfolded proteins bound to smHSP oligomers when the refolding capacity of smHSPs is exceeded. HSGs found in tomato (Solanum lycopersicum) consist of cytosolic smHSPs, HSP70, and heat stress transcription factors (Scharf et al., 1998). It is likely that the formation of complexes and conformational changes during heat stress are closely related to the function of smHSPs.

We have examined DcHSP17.7, a smHSP from carrot (Daucus carota L.). DcHSP17.7 has been characterized in a number of studies. Its constitutive expression enhanced cell viability and membrane stability in transgenic carrot cells and plants under heat stress (Malik et al., 1999). Furthermore, expression of an antisense construct of DcHSP17.7 gene resulted in reduced thermotolerance. It was the first demonstration that modification of the expression of a single smHSP can both increase and decrease thermotolerance in plants. When introduced into potato (Solanum tuberosum L.), a cool-season crop, across species lines, DcHSP17.7 enhanced cellular membrane stability and tuberization in vitro (Ahn and Zimmerman, 2006). These results suggested that DcHSP17.7 is a promising candidate to be used for the genetic engineering of heat-resistant crops. To understand the possible function and structural dynamics of DcHSP17.7, in this study, we introduced a coding sequence of DcHSP17.7 into Escherichia coli and studied its function in the transformed $E$. coli cells under heat stress.

\section{Materials and Methods}

Construction of transformed E. coli expressing DcHSP17.7. The coding region of the DcHSP17.7 gene (471 bp) was amplified by polymerase chain reaction (one cycle at $95{ }^{\circ} \mathrm{C}$ for $5 \mathrm{~min}$ followed by 35 cycles of $95^{\circ} \mathrm{C}$ for $1 \mathrm{~min}, 55^{\circ} \mathrm{C}$ for $1 \mathrm{~min}$, and $72{ }^{\circ} \mathrm{C}$ for $2 \mathrm{~min}$ ) using a set of primers (forward: $5^{\prime}$ GGGGGGCATATGTCGATCATTCCAAGC3', reverse: 5'-GGGGGGGCTAGCTTAAC CAGAAATATCAATGGC-3'). The forward primer contains an $\mathrm{NdeI}$ restriction enzyme site (underlined) overlapping the start codon of the gene and the reverse primer has a NheI restriction enzyme site (underlined) after the stop codon. The amplicon was double-digested with the two restriction 
enzymes and inserted into the pET11a expression vector (Novagen, Madison, WI). After confirming the sequence, the resulting $\mathrm{pET} 11 \mathrm{a}-\mathrm{DcHSP} 17.7$ recombinant vector was introduced into $E$. coli BL21 (DE3; Novagen).

Cell culture and expression of DcHSP17.7. E. coli cell culture and expression of DcHSP17.7 were performed according to the modified protocol of Yeh et al. (1997). Wildtype vector control containing unmodified pET11a and transformed cells containing pET11a-DcHSP17.7 were cultured in LuriaBertani (LB) broth containing $100 \mu \mathrm{g} \cdot \mathrm{mL}^{-1}$ of ampicillin overnight with shaking at $37{ }^{\circ} \mathrm{C}$. Overnight cultures were diluted 1:1000 with fresh LB broth containing ampicillin and continuously incubated at $37{ }^{\circ} \mathrm{C}$. When cell cultures were grown to an $\mathrm{OD}_{600}$ of 0.6 , isopropyl b-D-thiogalactopyranoside (IPTG) was added to a final concentration of $1 \mathrm{~mm}$ to induce the expression of DcHSP17.7. To determine cell growth rates, $\mathrm{OD}_{600}$ of cell cultures was measured every $30 \mathrm{~min}$ up to $7.5 \mathrm{~h}$.

Protein extraction and immunodetection of DcHSP 17.7. Total proteins of transformed $E$. coli were extracted at $2 \mathrm{~h}$ after IPTG treatment using a commercial kit $\left(\mathrm{SMART}^{\mathrm{TM}}\right.$ Bacterial Protein Extraction Solution; Intron, Seongnam, Korea) and quantified using a Bradford assay (Bradford, 1976). A total of $30 \mu \mathrm{g}$ of proteins was separated using SDSPAGE (12\%) and electroblotted to polyvinylidene difluoride (PVDF) membrane (BioRad, Hercules, CA). Immunoblot analysis was performed using a polyclonal antibody raised against DcHSP17.7 according to the instructions of the ECL Plus System (Amersham Biosciences, Pittsburgh, PA).

Thermotolerance of transformed $\mathrm{E}$. coli expressing DcHSP17.7. Overnight cell cultures (vector control and transformed $E$. coli expressing DcHSP17.7) were diluted 1:1000 and grown to an $\mathrm{OD}_{600}$ of 0.6 . Then, cell cultures were treated with IPTG and incubated at $37^{\circ} \mathrm{C}$ for an additional $2 \mathrm{~h}$. A total of $1 \mathrm{~mL}$ of cell cultures was subjected to $50{ }^{\circ} \mathrm{C}$ and $100 \mu \mathrm{L}$ of cells was collected at 0,30 , and $60 \mathrm{~min}$. Samples were diluted 1:1000 and plated on LB medium containing ampicillin (five plates per time point). Plates were incubated overnight at $37^{\circ} \mathrm{C}$ and the number of surviving colonies was counted. The experiment was repeated five times.

Solubility of proteins in transformed $\mathrm{E}$. coli expressing DcHSP17.7. Diluted overnight cell cultures were treated with IPTG as described previously. After $2 \mathrm{~h}$, cell cultures were subjected to $50{ }^{\circ} \mathrm{C}$. Similar number of cells was taken at 0,30 , and $60 \mathrm{~min}$ and soluble proteins were extracted as described previously. The amount of soluble proteins in each sample was determined using a Bradford assay (Bradford, 1976).

Complex formation of DcHSP17.7. Diluted overnight cell cultures were treated with IPTG as described previously. After $2 \mathrm{~h}$, cell cultures were subjected to $50^{\circ} \mathrm{C}$ up to $1 \mathrm{~h}$ and total proteins were extracted as described previously. Proteins from nonstressed and heat-stressed $\left(40{ }^{\circ} \mathrm{C}\right.$ up to $\left.12 \mathrm{~h}\right)$ carrot leaf tissues were obtained by homogenizing tissues in the extraction buffer $(50 \mathrm{~mm}$ Tris $\mathrm{HCl}$, $500 \mathrm{~mm} \mathrm{NaCl}, 25 \mathrm{~mm} \mathrm{KCl}, 5 \mathrm{~mm} \mathrm{MgCl}_{2}$, $30 \mathrm{~mm}$ EDTA, 5\% sucrose, 5\% glycerol, $14.2 \mathrm{~mm} \beta$-mercaptoethanol, and $0.5 \%$ Triton $\mathrm{X}-100)$ containing no denaturing agent. Protease inhibitor cocktail for plant cell and tissue extracts (Sigma-Aldrich, St. Louis, MO) was added to the buffer just before use. After lysate was centrifuged for $5 \mathrm{~min}$ at $10,000 \times g$, clear supernatant was taken. Proteins were quantified using a Bradford assay (Bradford, 1976) and 25 and $50 \mu \mathrm{g}$ of $E$. coli and carrot proteins, respectively, were resolved either on a $4 \%$ to $20 \%$ Native-PAGE gel (Biorad) or a $12 \%$ SDS-PAGE gel. Immunoblot analysis was performed as described previously.

\section{Results and Discussion}

Expression of DcHSP17.7 in E. coli. The gene encoding DcHSP17.7 was introduced into $E$. coli to examine its functional mechanism under heat stress. E. coli has been used as a convenient system in a number of studies examining plant smHSPs (Cho and Bae, 2007; Yeh et al., 1997). IPTG was added to the cell culture to induce the expression of DcHSP17.7. During initial growth stages before IPTG treatment, similar growth rates were observed for all types of cells (wild-type BL21, vector control containing unmodified pET11a, and transformed cells containing pET11a-DcHSP17.7; Fig. 1). When cells were treated with IPTG at $2 \mathrm{~h}$ after culture initiation, the wild type continued exponential growth and reached stationary phase at $4 \mathrm{~h}$ after culture initiation. However, the growth rates of vector control and transformed cells containing pET11a-DcHSP17.7 decreased on IPTG treatment.

To confirm the accumulation of DcHSP17.7 in the transformed E. coli, first, we attempted to visualize the protein using Coomassie staining. However, DcHSP17.7 was not distinguishable from bacterial proteins in the corresponding molecular mass region (data not shown), suggesting the low expression level of DcHSP17.7. To detect the possibly low amount of DcHSP17.7, immunoblot analysis was performed using a polyclonal antibody raised against DcHSP17.7. As shown in Figure 2, DcHSP17.7 was detected in the transformed $E$. coli containing pET11a-DcHSP17.7. Our results showed that DcHSP17.7 was expressed in the transformed E. coli but at a relatively low level. The low levels of DcHSP17.7 were previously observed when it was constitutively expressed in carrot (Malik et al., 1999) and potato (Ahn and Zimmerman, 2006), even under the control of the strong Cauliflower mosaic virus $35 \mathrm{~S}$ promoter. It is possible that the high level of DcHSP17.7 has adverse effects on metabolic processes in nonstressed cells; thus, its accumulation is tightly regulated.

Thermotolerance of transformed $\mathrm{E}$. coli expressing DcHSP17.7. To examine if heterologous expression of DcHSP17.7 can increase thermotolerance in E. coli, vector control and transformed cells expressing DcHSP17.7 were subjected to heat stress $\left(50{ }^{\circ} \mathrm{C}\right)$ up to $1 \mathrm{~h}$. Then, cell viability was measured by counting the number of surviving colonies of serially diluted samples. At 30 min after the temperature shift to $50{ }^{\circ} \mathrm{C}$, the survival rate of vector control cells decreased dramatically to $18 \%$ (Fig. 3). On the other hand, $75 \%$ of transformed cells expressing DcHSP17.7 survived under the same heat

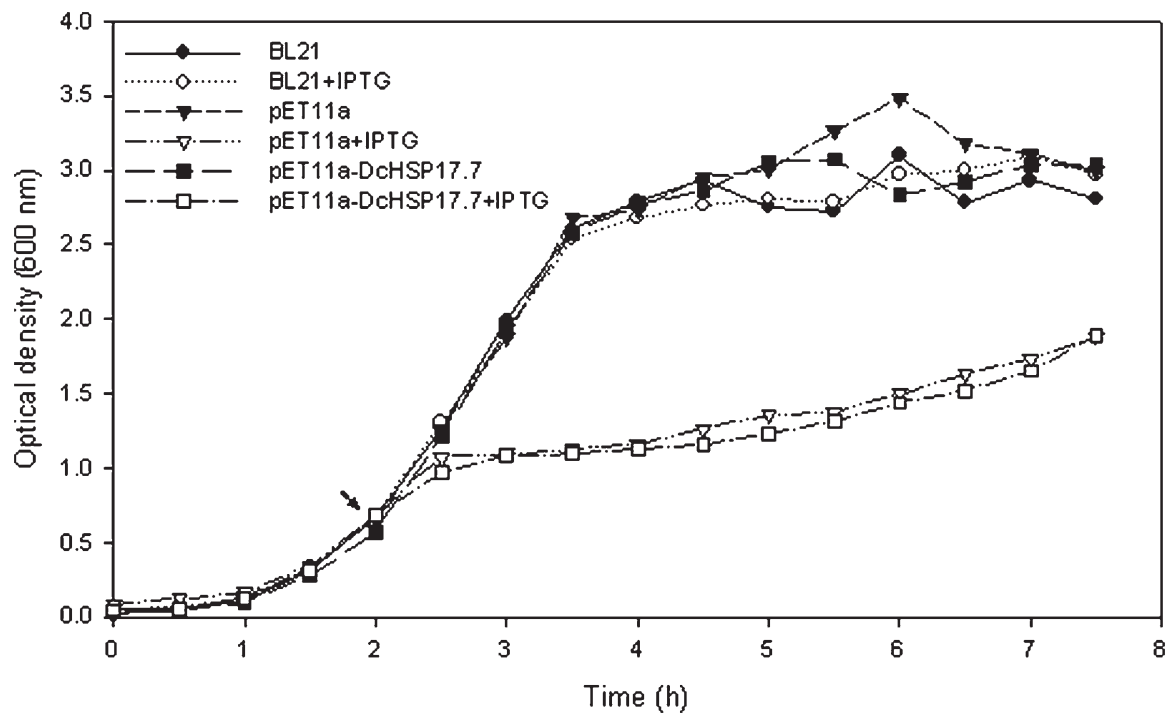

Fig. 1. Growth of Escherichia coli at $37^{\circ} \mathrm{C}$ with or without isopropyl b-D-thiogalactopyranoside (IPTG) treatment. Wild-type (BL21, DE3), vector control containing unmodified pET11a, and transformed cells containing pET11a-DcHSP17.7 were cultured in Luria-Bertani (LB) broth containing ampicillin at $37^{\circ} \mathrm{C}$ overnight. Overnight cultures were diluted 1:1000 with fresh LB broth containing ampicillin and incubated at $37^{\circ} \mathrm{C}$ until $\mathrm{OD}_{600}$ reached 0.6. Then, IPTG was added to a final concentration of $1 \mathrm{~mm}$ and incubated further at $37^{\circ} \mathrm{C}$. $\mathrm{OD}_{600}$ of cell cultures was measured every $30 \mathrm{~min}$ up to $7.5 \mathrm{~h}$. Arrow indicates the addition of IPTG. 


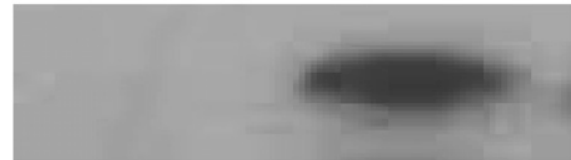

Fig. 2. Expression of DcHSP17.7 in transformed Escherichia coli. Cell culture and isopropyl bD-thiogalactopyranoside (IPTG) treatment were performed as described in "Materials and Methods." After $2 \mathrm{~h}$ of IPTG treatment, proteins were extracted from vector control containing unmodified pET11a and transformed cells containing pET11a-DcHSP17.7. A total of $30 \mu \mathrm{g}$ of proteins was separated using SDS-PAGE (12\%) and immunoblot analysis was performed using a polyclonal antibody raised against DcHSP17.7.

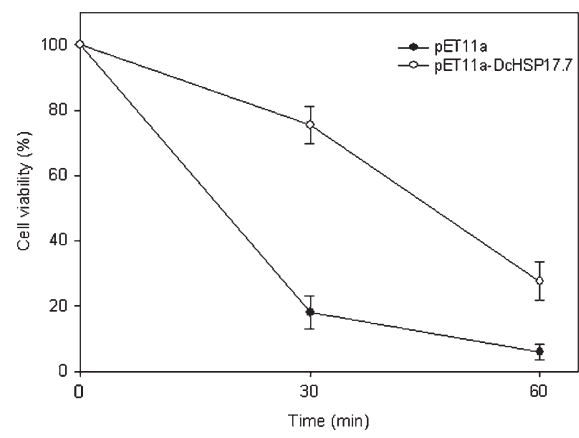

Fig. 3. Thermotolerance of transformed Escherichia coli expressing DcHSP17.7. Cell culture and isopropyl b-D-thiogalactopyranoside (IPTG) treatment were performed as described in "Materials and Methods." After $2 \mathrm{~h}$ of IPTG treatment, cell culture (vector control containing unmodified pET11a and transformed cells expressing DcHSP17.7) was subjected to $50{ }^{\circ} \mathrm{C}$ and samples $(100 \mu \mathrm{L}$ each) were collected at 0 , 30 , and $60 \mathrm{~min}$. Cells were diluted 1:1000 and plated on Luria-Bertani medium containing ampicillin. Plates were incubated at $37{ }^{\circ} \mathrm{C}$ overnight and the number of surviving colonies was counted.

stress condition showing $\approx 4$-fold higher cell viability than that of vector control. At 60 min, the survival rate of vector control further decreased to $5 \%$, whereas that of transformed cells expressing DcHSP17.7 was $28 \%$. Our result shows that the heterologous expression of DcHSP17.7 enhances cell viability in $E$. coli.

Solubility of proteins in transformed E. coli expressing DcHSP17.7. Under heat stress, molecular chaperones bind to partially denatured proteins to prevent further denaturation/aggregation and promote correct refolding of the proteins. We examined if DcHSP17.7 enhanced cell viability in transformed $E$. coli under heat stress, functioning as a molecular chaperone. When the amount of soluble proteins present in each sample was calculated, $60 \%$ of proteins in vector control were degraded after $1 \mathrm{~h}$ heating (Fig. 4). However, most proteins in transformed cells expressing DcHSP17.7 remained soluble at $50{ }^{\circ} \mathrm{C}$ up to $1 \mathrm{~h}$. Our result suggest that DcHSP17.7 may function as a molecular chaperone in transformed $E$. coli during heat stress, protecting proteins from degradation. It remains to be determined whether DcHSP17.7 functions directly or through interacting with other $E$. coli proteins such as bacterial HSPs.

Complex formation of DcHSP17.7. To examine if DcHSP17.7 forms oligomeric complexes, proteins from transformed $E$. coli expressing DcHSP17.7 and carrot leaf tissues were extracted under nondenaturing conditions and subjected to Native-PAGE and immunoblot analysis. In transformed $E$. coli expressing DcHSP17.7, on IPTG treatment, DcHSP17.7 was found in an oligomeric complex of $\approx 300 \mathrm{kDa}$ (Fig. 5A). However, when cells were exposed to an elevated temperature $\left(50^{\circ} \mathrm{C}\right.$, up to $\left.1 \mathrm{~h}\right)$, the oligomeric complex was rapidly disappeared. We did not observe any additional protein bands newly appeared on Native-PAGE during heat stress (data not shown). To examine if the disappearance of the complex was the result of heat-inducible degradation, proteins were also subjected to SDS-PAGE. As shown in Figure 5B, DcHSP17.7 was still present in transformed E. coli during heat stress, suggesting that the disappearance of the native complex containing DcHSP17.7 was not, at least entirely, the result of heat-inducible degradation. It is possible that in transformed E. coli during heat stress, DcHSP17.7 forms a higher-order complex such as HSGs, which are too big to enter the Native-PAGE gel but are able to be dissociated into monomers in the presence of SDS.

We also examined the complex formation of DcHSP17.7 in carrot. In nonstressed carrot leaf tissues, DcHSP17.7 was not present (Fig. 5C). However, on heat stress $\left(40^{\circ} \mathrm{C}\right.$, up to 12 h), DcHSP17.7 was accumulated and found in an $\approx 300-\mathrm{kDa}$ oligomeric complex, similar in size to the complex found in transformed E. coli. The amount of the complex increased as heat stress continued. Suzuki et al. (1998) also reported that the Arabidopsis HSP21 complex $(300 \mathrm{kDa})$ formed in vivo did not dissociate during heat stress. It is possible that in plants, the large smHSP oligomers are the functional species. SDS-PAGE analysis also showed continued accumulation of DcHSP17.7 during heat stress (Fig. 5D).

In cyanobacterium (Giese and Vierling, 2002), human (Shashidharamurthy et al., 2004), and Mycobacterium tuberculosis (Yang et al., 1999), the oligomeric complexes containing smHSPs dissociate into smaller complexes under heat stress. It has been suggested that the dissociation may expose the hydrophobic areas of smHSPs to interact with hydrophobic regions of denatured proteins (Lee et al., 1997; Lindner et al., 2000), increasing affinity to substrates. Dissociation into smaller complexes may also facilitate substrate

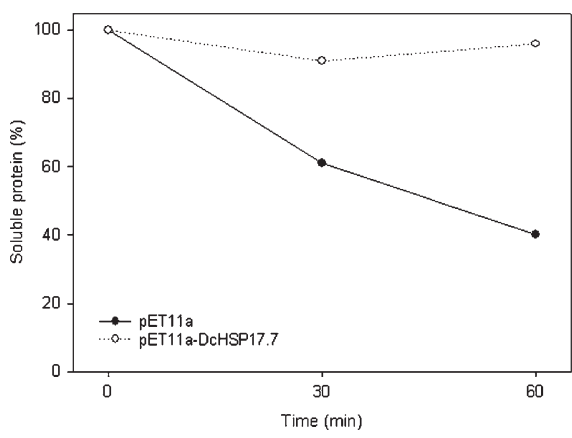

Fig. 4. Solubility of proteins in transformed Escherichia coli expressing DcHSP17.7. Cell culture and isopropyl b-D-thiogalactopyranoside (IPTG) treatment were performed as described in "Materials and Methods." After $2 \mathrm{~h}$ of IPTG treatment, cell cultures (vector control containing unmodified pET11a and transformed cells expressing DcHSP17.7) were heat-stressed at $50{ }^{\circ} \mathrm{C}$ and similar number of cells were collected by centrifugation at 0,30 , and $60 \mathrm{~min}$. Soluble proteins were extracted and the amount in each sample was quantified using a Bradford assay (Bradford, 1976).

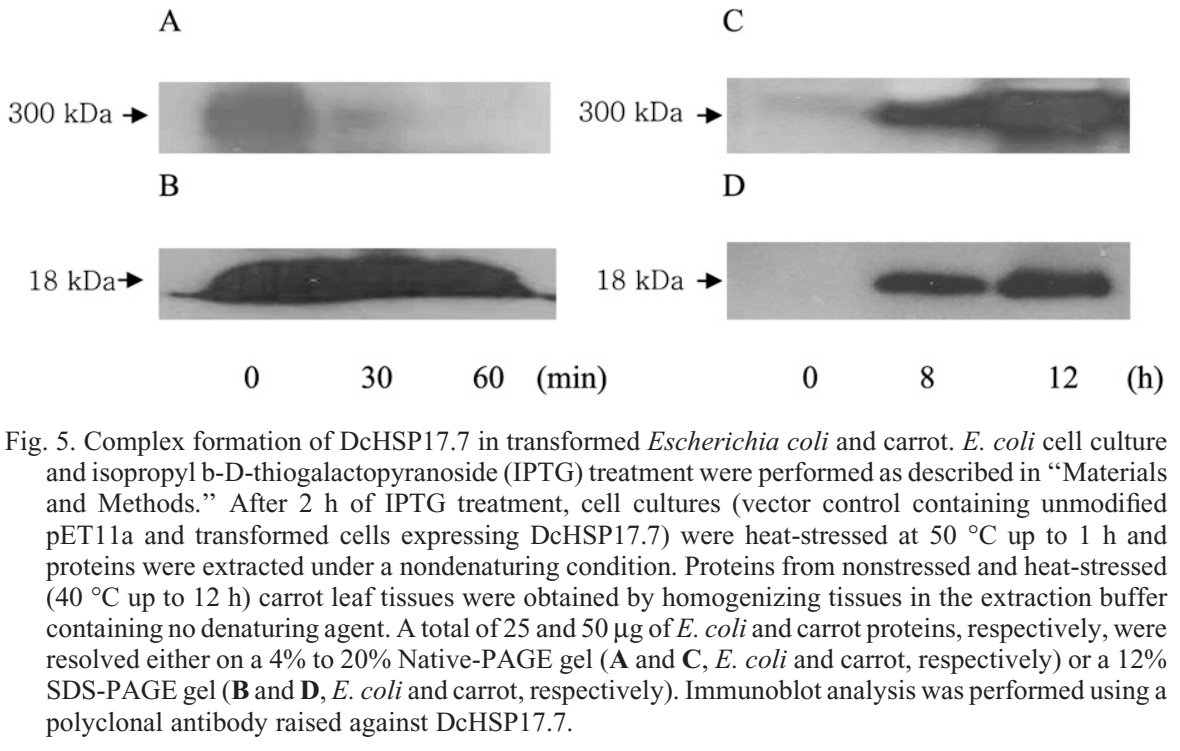


binding through exposing substrate binding sites buried in the oligomeric complexes.

\section{Literature Cited}

Ahn, Y.-J. and J.L. Zimmerman. 2006. Introduction of the carrot HSP17.7 into potato (Solanum tuberosum L.) enhances cellular membrane stability and tuberization in vitro. Plant Cell Environ. 29:95-104.

Basha, E., K.L. Friedrich, and E. Vierling. 2006. The N-terminal arm of small heat shock proteins is important for both chaperone activity and substrate specificity. J. Biol. Chem. 281: 39943-39952.

Bradford, M.M. 1976. A rapid and sensitive method for the quantitation of microgram quantities of protein utilizing the principle of protein-dye binding. Anal. Biochem. 72:248254.

Cho, E.K. and S.-J. Bae. 2007. ATP-independent thermoprotective activity of Nicotiana tabacum heat shock protein 70 in Escherichia coli. J. Biochem. Mol. Biol. 40:107-112.

DeRocher, A.E., K.W. Helm, L.M. Lauzon, and E. Vierling. 1991. Expression of a conserved family of cytoplasmic low molecular weight heat-shock proteins during heat stress and recovery. Plant Physiol. 96:1038-1047.

Giese, K.C. and E. Vierling. 2002. Changes in oligomerization are essential for the chaperone activity of a small heat shock protein in vivo and in vitro. J. Biol. Chem. 277:46310-46318.

Haslbeck, M., T. Franzmann, D. Weinfurtner, and J. Buchner. 2005. Some like it hot: The structure and function of small heat-shock proteins. Nat. Struct. Mol. Biol. 12:842-846.

Hsieh, M., J. Chen, T. Jinn, Y. Chen, and C. Lin. 1992. A class of soybean low molecular weight heat-shock proteins. Plant Physiol. 99:12791284.

Keller, C.F. 2007. Global warming 2007. An update to global warming: The balance of evidence and its policy implications. Scientific World Journal 9:381-399.

Kirschner, M., S. Winkelhaus, J.M. Thierfelder, and L. Nover. 2000. Transient expression and heat-stress-induced co-aggregation of endogenous and heterologous small heat-stress proteins in tobacco protoplasts. Plant J. 24: 397-411.

Lee, G.J., A.M. Roseman, H.R. Saibil, and E. Vierling. 1997. A small heat shock protein stably binds heat-denatured model substrates and can maintain a substrate in a foldingcompetent state. EMBO J. 16:659-671.

Lindner, R.A., J.A. Carver, M. Ehrnsperger, J. Buchner, G. Esposito, J. Behlke, G. Lutsch, A. Kotlyarov, and M. Gaestel. 2000. Mouse Hsp25, a small shock protein. The role of its C-terminal extension in oligomerization and chaperone action. Eur. J. Biochem. 267:19231932.

Lobell, D.B. and C.B. Field. 2007. Global scale climate-crop yield relationships and the impacts of recent warming. Environ. Res. Lett. 2:014002.

Malik, M.K., J.P. Slovin, C.H. Hwang, and J.L. Zimmerman. 1999. Modified expression of a carrot small heat shock protein gene, hsp17.7, results in increased or decreased thermotolerancedouble. Plant J. 20:89-99.

Pollock, C.J., C.F. Eagles, C.J. Howarth, P.H.D Schunmann, and L.L. Stoddart. 1993. Temperature stress, p. 109-132. In: Fowden, L., T. Mansfield, and J. Stoddart (eds.). Plant adaptation to environmental stress. Chapman \& Hall, London, UK.

Scharf, K.D., H. Heider, I. Höhfeld, R. Lyck, E. Schmidt, and L. Nover. 1998. The tomato Hsf system: HsfA2 needs interaction with HsfA1 for efficient nuclear import and may be localized in cytoplasmic heat stress granules. Mol. Cell. Biol. 18:2240-2251.

Scharf, K.D., M. Siddique, and E. Vierling. 2001. The expanding family of Arabidopsis thaliana small heat stress proteins and a new family of proteins containing alpha-crystallin domains (Acd proteins). Cell Stress Chaperones 6:225237.

Shashidharamurthy, R., H.A. Koteiche, J. Dong, and H.S. McHaourab. 2004. Mechanism of chaperone function in small heat shock proteins: Dissociation of the HSP27 oligomer is required for recognition and binding of destabilized T4 lysozyme. J. Biol. Chem. 280:52815289.

Sun, W., M. Van Montagu, and N. Verbruggen. 2002. Small heat shock proteins and stress tolerance in plants. Biochim. Biophys. Acta 1577:1-9.

Suzuki, T.C., D.C. Krawitz, and E. Vierling. 1998. The chloroplast small heat-shock protein oligomer is not phosphorylated and does not dissociate during heat stress in vivo. Plant Physiol. 116:1151-1161.

Wahid, A., S. Gelani, M. Ashraf, and M.R. Foolad. 2007. Heat tolerance in plants: An overview. Environ. Expt. Bot. 61:199-223.

Waters, E.R., G.J. Lee, and E. Vierling. 1996. Evolution, structure and function of the small heat shock proteins in plants. J. Expt. Bot. 47:325-338.

Yang, H., S. Huang, H. Dai, Y. Gong, C. Zheng, and Z. Chang. 1999. The Mycobacterium tuberculosis small heat shock protein Hsp16.3 exposes hydrophobic surfaces at mild conditions: Conformational flexibility and molecular chaperone activity. Protein Sci. 8:174-179.

Yeh, C.H., P.F. Chang, K.W. Yeh, W.C. Lin, Y.M. Chen, and C.Y. Lin. 1997. Expression of a gene encoding a $16.9-\mathrm{kDa}$ heat-shock protein, Oshsp16.9, in Escherichia coli enhances thermotolerance. Proc. Natl. Acad. Sci. USA 94:10967-10972.

Young, L.S., C.H. Yeh, Y.M. Chen, and C.Y. Lin. 1999. Molecular characterization of Oryza sativa $16.9 \mathrm{kDa}$ heat shock protein. Biochem. J. 344:31-38. 